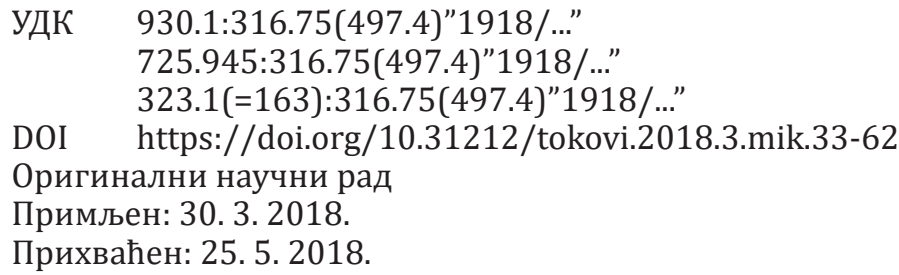

Peter MIK ̌̌A

University of Ljubljana, Faculty of Arts,

Department of History, Ljubljana peter.miksa@ff.uni-lj.si.

\title{
Yugoslavism Written in Memorials and Denominations in Ljubljana
}

\begin{abstract}
The purpose of the article is to present a (chronological) overview of denomination, renaming or abolishing streets and squares, setting up and tearing down monuments, naming and renaming primary schools, etc. of Yugoslav connotation in Ljubljana from 1918 onwards. This kind of establishing of collective memory in Slovenia is most evident in political fractures, such as: fracturing from the Austro-Hungarian monarchy and entering the State of Slovenes, Croats and Serbs, and the Kingdom of Serbs, Croats and Slovenes, when it was necessary to redefine the collective memory and clean up the old. This is most evident in renaming streets and institutions or tearing down and putting up new monuments. Or furthermore, the more striking marking of space: the post-war regime in the time of the "second" Yugoslavia. The process was also present during the period of occupation of Slovenia between 1941 and 1945; and during the post-independence Slovenia after the year 1991.
\end{abstract}

Key words: Yugoslavism, Yugoslavia, monuments, Slovenia, Ljubljana

\section{Introduction}

Monuments, ${ }^{1}$ memorials and denominations are tools of collective memory, ${ }^{2}$ established, consolidated and renewed through them. Col-

1 The Dictionary of Slovenian Literary Language defines monument as a sculptural or architectural work in memory of a particular person or event. SSKJ, „Spomenik“, datum pristupa 30. 1. 2018, http://bos.zrc-sazu.si/cgi/a03.exe?name=sskj_testa\&expression=spomenik\&hs $=1$.

2 The term "collective memory" defines how a group represents its past. It includes the past, which the community shares and which it commemorates. This past legislates 
lective memory arises in the process of selective processing, which preserves some memories and discards others. ${ }^{3}$ Therefore, "control" over collective memory is a very important mechanism of individual social groups in power, since in this way they control and shape identity, even with the help of oblivion.

The 20th century occupies a special place in the history of public monuments. We could even say it is a century of "monumentalism," since monuments and memorials are an extremely important visual medium and contribute to the design and justification of different national and state identities and help in spreading and creating collective memory. ${ }^{4}$ The memory of certain historical figures and their actions on the one hand speaks of the existence of a community in time and space; that is, the existence of a nation. On the other hand, it testifies to the power and reach of a certain political influence in a certain area. ${ }^{5}$

Representations of people, events, etc., in the form of memorials, such as inscriptions, sculptures, monuments, etc. (including the naming of streets, squares, schools, etc.) serves the commemorative marking of matters that are of cultural or ideological importance to a specific nation or bearers of the domain of the national. It is necessary to immortalize certain ideas or individuals that represent (have represented) or embody (have embodied) a certain idea. By erecting (or removing) public monuments and memorials, social groups are able to form collective memo-

and grants the substance of the identity of the group, its current state and the vision of the future. Barbara A. Misztal, Theories of Social Remembering, (Maidenhead, Philadelphia: Open University Press, 2003), 158. - In Slovenian, the term "collective memory" translates as "kolektivni spomin", which is not entirely accurate. Scientists Taja Kramberger and Marija Jurić Pahor warn about the terminological incompatibility of the translation. They use the term "memoria" and they emphasize that the terms "memory" and "memoria" cannot be equated. Memoria is a neurophysiological function, while memory is a related cognitive-psychic structure, which must first become aware before it can be communicated, articulated. Cit. by Sigfried J. Schmidt in: Marija Jurić Pahor, "Memorija in/ali spomin? Raziskovalni trendi in pojmovne zagate", Razprave in gradivo, 2007, 53-54, 208-209. See also: Taja Kramberger, Historiografska divergenca: razsvetljenska in historična paradigma: o odprti in zaprti epistemični strukturi in njunih elaboracijah, (Koper: Založba Annales, 2007), 63 (footnote 64).

3 Taja Kramberger, "Zapletena razmerja: Spomin, memorija, pozaba, zgodovina", Emzin, 2009, XIX, 3-4, 55-57.

4 Nenad Makuljević, Barbara Murovec, "Uredniška beseda”, Acta historiae artis Slovenica, 2013, XVIII, 2, 3.

5 Božidar Jezernik, "Moč spomina, premoč pozabe: Zgodovina ljubljanskih 'nacionalnih spomenikov'”, Zgodovina za vse: vse za zgodovino, 2004, XI, 1, 14. 
ries, and therefore national identity, since they immortalize certain ideas or individuals who represent or embody an idea. ${ }^{6}$

When monuments disappear, it is a good example of a change in the collective memory, when the "old" no longer corresponds to the "new", or when old symbols no longer fit into a new ideology.7 Therefore, if monuments are understood as a medium that helps us form collective memories, their removal helps us forget or forces us into oblivion. ${ }^{8}$

This is most evident in political fractures, when it is necessary to redefine a collective memoria and get rid of an old one - most visible in the renaming of streets and institutions and tearing down and erecting new monuments. There were numerous political fractures on Slovene territory in the 20th century, all of which relate to the Yugoslav story. First, after the disintegration of the Austro-Hungarian Empire in 1918, the territory joined the Kingdom of Serbs, Croats and Slovenes; then, followed the occupation by all four neighbors and the end of the "first" Yugoslavia in 1941; then came the end of the war and the period of the "second" Yugoslavia in 1945; and finally, the separation of Slovenia from Yugoslavia and its resulting independence. All four fractures embody the idea of unifying the Yugoslav nations into a common state, which could be described as one of the most important features of 20th century Slovenian history. Not only as an idea; the Slovenes had been part of a political formation of this name for over 70 years. There is an especially important period in the context of the presented topic, namely the period during which Slovenia was a part of the so-called "new" Yugoslavia, which had the longest lifespan among all the Yugoslavia-forming projects - and as far as Yugoslavism is concerned in the form of this topic, it had the greatest role.

\section{Yugoslavism in Memory and Space}

The elements of Yugoslavism are still present in Slovene collective memory, which is evident in numerous memorials and denominations found in the Slovene public space, associated with Yugoslavism. Their emergence can be traced back to the 1920s, while most of them were recorded in the second half of the 20th century. Erecting monuments and

6 Božidar Jezernik, Mesto brez spomina: Javni spomeniki v Ljubljani, (Ljubljana: Modrijan, 2014), 13.

$7 \quad$ Politika praznovanja: prazniki in oblikovanje skupnosti na Slovenskem, ed. Božidar Jezernik, (Ljubljana: Filozofska fakulteta, 2013).

8 Jasmina Čubrilo, "Dva spomenika Sretena Stojanovića: Kontinuiteta v diskontinuiteti", Acta historiae artis Slovenica, 2013, XVIII, 2, 73. 
denominations are always linked to an ideological orientation of the ruling political group. There was a clear political goal in this case as well. The first objective was consolidating Yugoslav wartime unitarism and evoking the memory of the national liberation struggle during World War II.

First, the regime celebrated the King, then the memory of war heroes, events, or important political figures, through which the rebellious spirit of the Slovene and Yugoslav peoples was manifested. After the breakup of Yugoslavia and the independence of Slovenia and its reorientation to Western neoliberalism, in many cases "Yugoslav" squares, roads and streets were given more "neutral" names. Frequently, monuments of Yugoslav connotation became undesirable and were removed as the most significant examples of memorials.

The aforementioned processes will be discussed in the article on the example of Ljubljana, namely in practical examples from before, during and after the fractures - in the years 1918, 1941, 1945, and 1991. The purpose of the article is to make a chronological overview of the most prominent renaming or abolition of streets and squares; (attempted) erections and removals of monuments; naming and renaming establishments, etc. from the end of World War I through World War II, and the beginning of the 1990s. We will proceed from the assumption that the process of formation was the most intensive in the period after World War II. However, the said memorials and denominations were part of a reverse process after the independence of Slovenia, namely of erasing or removing. This process was inextricably linked to the current post-independence ideology, the essence of which was in general the denial of Yugoslavism and a turn to the Western European democracies.

\section{Kaiser Gives Way to King (1918-1941)}

The idea of forming a nation was, by and large, always shaped against some other, mostly already formed national concept. Thus, the identity of the Slovenes was shaped against the Germans in the 19th century, despite the fact these two groups had shared a common state until the end of World War I. ${ }^{9}$ An important issue of "our" and "foreign" arose.

9 The national struggle is evident in all areas of national activity: politics, economy, science and culture. As an important part of this culture, physical activity gradually came into prominence: gymnastics, sports and mountaineering. Even in this area, there were frictions, even excesses (brawls between the Germans and Slovenes), while in the mountaineering, a real battle for the mountains between the German and Slovenian mountain societies went on, reaching the peak in 1895 with the pur- 
The foreign or "not ours" became the Germans who lived in the same state as "we", but they were not "our" brothers in blood or tongue. Thus, the dynasty of the Hapsburgs, which the Kaiser embodied as the Father of the nation during the "national awakening," had become the "foreign" ruler. ${ }^{10}$ By joining the Kingdom of the SHS, ${ }^{11}$ the previously "foreign" Serbian King of the House Karadjordjević had become "our" Slovenian King. Soon, everything that in any way evoked the Austro-Hungarian period, started to disappear.

\subsection{Removal of Monuments}

"In the evening of December 30, 1918, between 8 and 10, the symbols of slavery and thralldom fell in Ljubljana. Four patriotic boys from Primorska, armed with chisels, grappling hooks and about 40 meters of rope, began an operation of removing the monuments of shameful enslavement. The first to fall was the fat-headed Radetzky ${ }^{12}$ in Zvezda square." ${ }^{\prime 3}$ Descriptions of the razing of Austrian monuments shed some light on the disappearance of any memory of the previous regime. The monument to the Austrian Field Marshal was just one of many that were destroyed in Ljubljana shortly after the

chase of the Triglav summit. See: Peter Mikša, ,'Da je Triglav ostal v slovenskih rokah, je največ moja zasluga.' Jakob Aljaž in njegovo planinsko delovanje v Triglavskem pogorju“" Zgodovinski časopis, 2015, LXIX, 1/2, 112-123.

10 Božidar Jezernik, Nacionalizacija preteklosti, (Ljubljana: Znanstvena založba Filozofske fakultete Univerze v Ljubljani, 2013), 21-23.

11 On October 29, 1918, the State of Slovenes, Croats and Serbs (State of SHS) was formed in Zagreb. It was a state of a confederate type and it included the territory of the South Slav nations of the former Austro-Hungarian Empire. It existed only until the unification with the Kingdom of Serbia on December 1, 1918. See: Jurij Perovšek, "Jugoslovanska združitev", Slovenska novejša zgodovina: od programa Zedinjena Slovenija do mednarodnega priznanja Republike Slovenije: 1848-1992, I-II, ed. dr. Jasna Fischer, (Ljubljana: Mladinska knjiga, 2005), I/200-201.

12 The Count Radecky (Radecki/Radetzky) was named a honorary citizen by the City Council of Ljubljana on September 5, 1852. They wanted to erect a monument in his natural size the following year. The statue was actually set up in 1880 (although Kažipot Ljubljana writes it was set up in 1882) in front of the Podturn castle in Tivoli. His bust was ceremoniously placed and opened on March 19, 1860, at the Congress Square (Zvezda Park, Božidar Jezernik, Mesto brez spomina: Javni spomeniki $v$ Ljubljani, (Ljubljana: Modrijan, 2014), 58-60). The monuments of Count Radecky symbolized the loyalty of the Duke of Carniola to the Hapsburg Monarchy, so consequently, many events denoting the nobility of Ljubljana and her permanent loyalty occurred there. Both statues were removed on New Year's Eve in 1918. Engelbert Gangl, Kažipot Ljubljana, Gorenjsko, Notranjsko s Postojno, Dolenjsko, Trst, (Ljubljana: Slovenska Sokolska Zveza, 1914), 13.

13 Jugoslavija, II, 1, 1.1.1919, 3. 
end of World War I. Naturally, the monuments causing the most wrath were those of Kaiser Francis Joseph I. They were built in Ljubljana in the second half of the 19th century. ${ }^{14}$ Half a century later, all the "devotion" to the Kaiser was gone, and while the statues were removed, the Slovenian newspapers merely said: "Ljubljana shall not cry for that man."15

Nowadays, no statues of Francis Joseph can be found in any public spaces in Ljubljana, but a trace of the statue's existence can be seen at the base of the statue of Fran Miklošič, built in 1926. This is the only remaining statue, since when it was removed, only the head was taken away, and replaced with the one of Miklošič. ${ }^{16}$

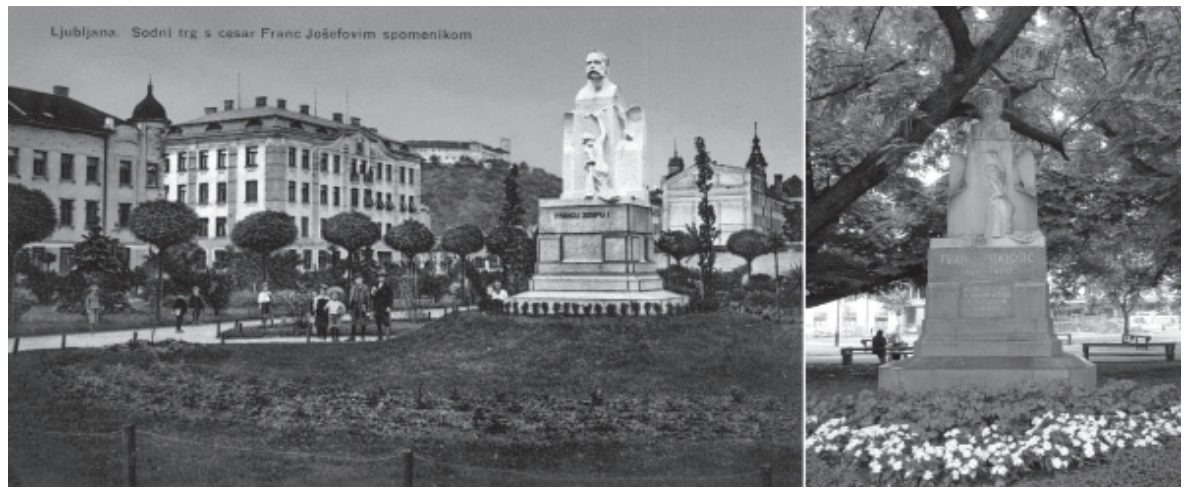

On the left, a monument to Franz Joseph, whose head had been removed in 1919 and replaced with the head of Fran Miklošič in 1926. (Sources of photographs: left, National Museum of Contemporary History, right, Veronika Škofljanec)

\subsection{Renaming of Streets, Squares, Bridges, and Institutions}

In July 1919, a massive renaming of streets and squares took place in Ljubljana - streets that in any way reminded of the Austro-

14 The citizens of Ljubljana got their own in 1862, when the Emperor himself donated his bust to the provincial shooting club on its 300th anniversary, and it was placed in the regional shooting club hall. Ljubljana received the second statue in 1883 on the sixth anniversary of the unification of the Duchy of Carniola with the Hapsburg Monarchy. The first public placement of the statue of Francis Joseph, however, was caused by the earthquake in 1895, when the Kaiser was one of the first to respond and send help to Ljubljana. The competition for the statue was announced in 1903, and in the year 1908, it was erected in the park in front of the court palace (Court Square, today the Slovene Square). The next statue of Francis Joseph was placed on August 18, 1916, in front of the Ljubljana castle on the day of the Kaiser's birthday. Jezernik, Mesto brez spomina, 194-206.

15 Jugoslavija, II, 1, 1. 1.1919, 3.

16 Ksenija Rozman, “Ljubljanski javni spomeniki”, Kronika, 1965, XIII, 2, 199. 
Hungarian period or the loyalty of the inhabitants of Ljubljana to the dual monarchy. ${ }^{17}$ They also renamed the main bridges over the Ljubljanica River, named after Austrian rulers. All of them received new names, mostly based on their location (Franciscan Bridge, Šentjakob Bridge, Dragon Bridge) ${ }^{18}$ In our context, however, the name of the University of the Kingdom of Serbs, Croats and Slovenes, founded in 1919 in Ljubljana, was especially interesting. Ten years later, on April 18, 1929, during an audience with King Alexander I, the rector of the University of Ljubljana asked him to sponsor the celebration of the 10th anniversary of the establishment of the university, which the king accepted. Befittingly, the university was renamed to the University of King Alexander I (Alma Mater Alexandrina). ${ }^{19}$ Of course, the newspapers did not report at that time that the renaming of the university was more of an act of saving the institution from being shut down rather than just the king's expression of love for the Slovene nation.

\subsection{Building Monuments}

A bronze bust of King Peter I Karadjordjević was placed in the vestibule of the rectorate of the University of Ljubljana as early as 1920 . It was the only such case of Yugoslavian eternalization for a decade. The majority of monuments and memorials came in the thirties, especially after the assassination of King Alexander I in Marseille in 1934.

\subsubsection{The Statue of King Peter I}

In November 1926 the people of Ljubljana decided to build a mighty statue of King Peter I, "the genius of our fortunate fate and the prophet of the glorious days of our national future." ${ }^{20}$ An executive committee was organized to issue a public request, calling on all Slovenes to

17 Historical Archives Ljubljana (ZAL Lj), Cod. III/77 (1919), fol. 128 sl. 5; Reg. I fasc 1615; fol. 275; Reg. I fasc 2047, fol. 126 in 805 sl; Jugoslavija, II, 171, 17. 7. 1919, 4.

18 ZAL Lj, Cod. III/77 (1919), fol. 128 sl. 5; Reg. I fasc 1615; fol. 275; Reg. I fasc 2047, fol. 126 in 805 sl; Andrej Mrak, "Kako so Ljubljančani 'pospravili' za Habsburžani in se prikupili novim oblastnikom. Zamenjava imen ljubljanskih ulic po prvi svetovni vojni", MMC RTV SLO, March 102012 Ljubljana, date of access: 25. 2. 2018, http://www. rtvslo.si/kultura/drugo/kako-so-ljubljancani-pospravili-za-habsburzani-in-se-prikupili-novim-oblastnikom/278607.

19 Petdeset let Slovenske Univerze v Ljubljani 1919-1969, editor dr. Roman Modic, (Ljubljana: Univerza v Ljubljani, 1969), 78.

20 Jugoslovan, II, 207, 7. 9. 1931, 2. 
contribute funds in their capacity for the installation of the monument. The committee also distributed about five thousand applications to various wealthy businesses and private individuals, but the response was not massive. ${ }^{21}$ After five years, the money was finally collected, and the monument was placed in front of the town hall. It was quite modest compared to earlier ambitious plans. For example, Slovenian art critic Karel Dobida suggested that the statue be placed on a high pillar in the middle of Dunajska Street or at the end of Miklošičeva Road, or even to build an entirely new square for the monument. ${ }^{22}$ It was ceremoniously opened on September 6, 1931, measuring 4 meters in height together with the base. The inscription said, "Our Liberator." 23 The newspapers on the previous day wrote: "The news about the unveiling of the statue of Peter - The Rock on which our free state was built, echoes all over Slovenia."24

\subsubsection{The Statue of King Alexander I the Unifier}

On November 11, 1934, two days after his assassination, the National Delegation passed a legislative proposal giving King Alexander the official title of the Knight King Alexander I the Unifier. ${ }^{25}$ The king's death was mourned by most Yugoslavs, because in addition to the tragic nature of the death itself, people also felt a sense of endangerment and uncertainty about their future. The king was not only the national leader, but also the main representative of the Yugoslav idea and principles. ${ }^{26}$ The unprecedented shock was followed by the idea of preserving the memory of the deceased ruler, which also meant erecting several monuments in his honor. Four statues and seven memorial plaques were placed, and several memorial linden trees were planted ${ }^{27}$ in the following years in Ljubljana:

21 Jezernik, Mesto brez spomina, 395.

22 Renata Komić Marn, "Možje na konjih: Vloga in recepcija konjeniškega spomenika na Slovenskem", Acta historiae artis Slovenica, 2013, XVIII, 2, 97.

23 Slovenec, vol. LIX, 201, 6. 9.1931, 2.

24 Slovenski narod LXIV, 201, 5. 9.1931, 3.

25 „Splošni pregled k tragediji v Marseille-u“, Kronika slovenskih mest, št. 4, 343.

26 Jezernik, Mesto brez spomina, 413-416.

27 For example, a memorial lime tree honoring King Alexander was planted on December 1,1934, by the fire station in Moste, Ljubljana (Jutro: Monday issue XV, 277a, 3.12. 1934). Another memorial lime tree honoring King Alexander was planted on December 1, 1934, at the Primary School in Rudnik (Jutro XV, 289, 16.12.1934) etc. 
- Monuments

- Monument to King Alexander, lobby of the University of Ljubljana's Rectorate (February 8, 1936) ${ }^{28}$

- Monument to King Alexander, Vič, Ljubljana (May 12, 1935) ${ }^{29}$

- Monument to King Alexander, in front of the Tobacco Factory in Ljubljana (June 16, 1935) ${ }^{30}$

- Monument to King Alexander, Zvezda Park, Ljubljana (September 6, 1940) ${ }^{31}$

- Memorial plaques

- Memorial plaque to King Alexander, in front of the school in Ježica, Ljubljana (December 7, 1934) ${ }^{32}$

- Memorial plaque to King Alexander, in front of the arsenal workshop on Kobarid Street 6, Bežigrad, Ljubljana (October $6,1935)^{33}$

- Memorial plaque to naming the teachers' home after King Alexander, Teachers' Home, Ljubljana (December 1, 1935) ${ }^{34}$

- Memorial plaque to King Alexander, lobby of elementary school on Zaloška road, Moste, Ljubljana (September 6, 1936) ${ }^{35}$

- Memorial plaque to King Alexander, school in Grabno, Ljubljana (June 28, 1937) ${ }^{36}$

- Memorial plaque to King Alexander, lobby of school in Barje, Ljubljana (June 28, 1937) ${ }^{37}$

- Memorial plaque to King Alexander, Hall in Sokol II Home, Trnovo, Ljubljana (November 9) ${ }^{38}$

The most important of all the monuments is the one honoring King Alexander, built in 1940 (even though preparations for the installation began in the year of his death). The importance of King Alexander was

28 Jutro XVII, 33, 9. 2.1936.

29 Jutro XVI, 122, 28. 5. 1935.

30 Jutro: Monday issue XVI, 24,17.6.1935.

31 Špelca Čopič, Javni spomeniki v slovenskem kiparstvu prve polovice 20. stoletja, (Ljubljana: Moderna galerija, 2000), 370-375.

32 Slovenski narod LXVII, 277, 7.12.1934.

33 Slovenski narod LXVIII, 227, 7.10.1935.

34 Učiteljski tovariš LXXV, 48, 5. 12.1935.

35 Jutro: Monday issue XVII, 36, 7.9.1936.

36 Tedenske slike: supplement to Domovina XIII, 28, 8. 7.1937.

37 Jutro XVIII, 148, 29.6.1937.

38 Jutro: Monday issue XXI, 234a, 7.10.1940. 
to be expressed by the right choice of location where the monument was supposed to stand. In the end, they decided in favor of Zvezda Park, while the date of unveiling the statue was scheduled for September 6, 1940. ${ }^{39}$ In its final form, the statue represented King Alexander on a horse as a soldier and warrior on a triumphant march, while the nation gave him the scepter as a symbol of power. The statue of the horse and rider measured 6.8 meters and stood on a base four meters high. ${ }^{40}$

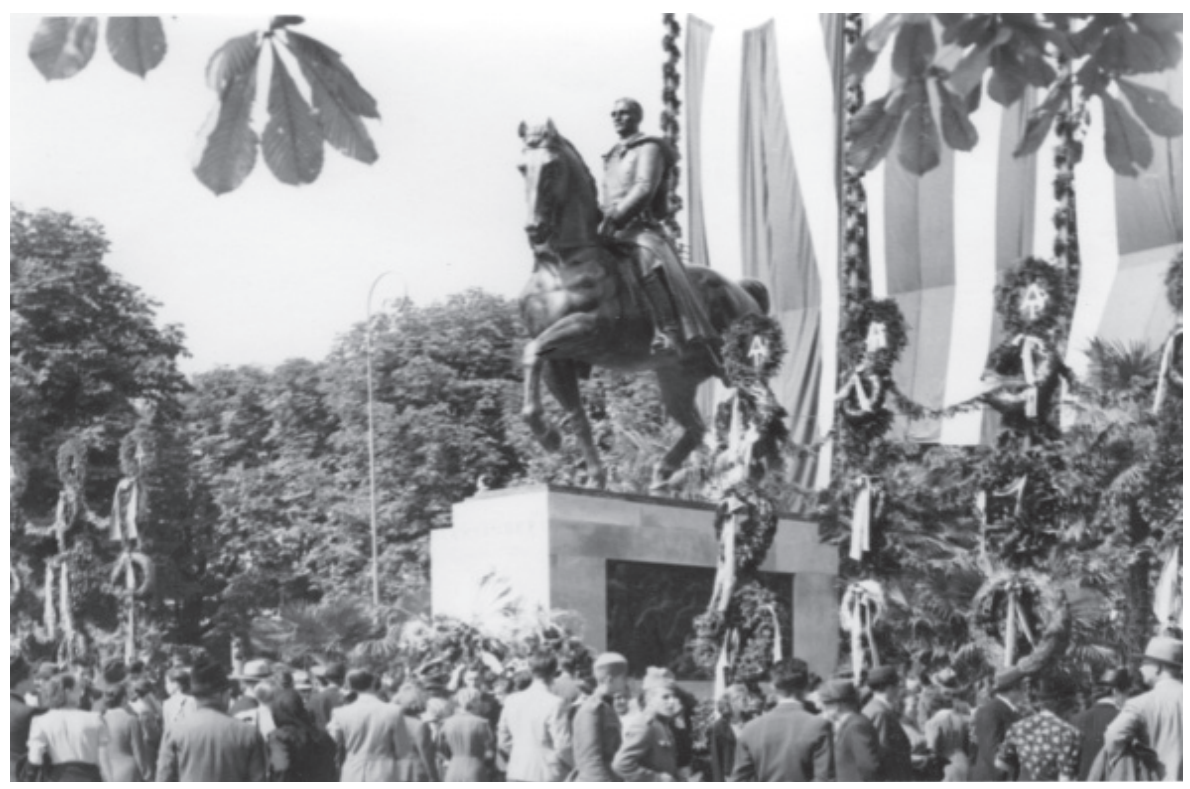

Statue of King Alexander I on Zvezda Square, built on September 6, 1940. (Source of photograph: National Museum of Contemporary History)

\section{The Occupation of Ljubljana (1941-1945)}

Immediately after its occupation in April 1941, the Slovene ethnic territory was divided among the four occupying forces: Germany, Italy, Hungary, and the Independent State of Croatia (NDH). ${ }^{41}$ The demarcation between the occupation zones (actually new state borders for the Axis powers) was determined by Hitler. ${ }^{42}$ The territories occupied by the

\footnotetext{
39 Ibid., 2.

40 Ibid., 428.

41 Božo Repe, S puško in knjigo: narodnoosvobodilni boj slovenskega naroda 1941-1945, (Ljubljana: Cankarjeva založba, 2015), 19.

42 Ibid., 20.
} 
Germans, Italians, Hungarians, and Croats, changed their characteristics and image, as the invader wanted to erase all historical memory of the common state of the Southern nations. ${ }^{43}$ Italy got the majority of Notranjska, most of Dolenjska and Ljubljana under its occupation. The territory was retained in one administrative unit, the Province of Ljubljana (Provincia di Lubiana), which was formally incorporated into the Kingdom of Italy on May 3, 1941.44

How did the Italian invader, who occupied Ljubljana between 1941 and 1943 and surrounded it with barbed wire, ${ }^{45}$ change the city's image? They wanted to erase the idea of Yugoslav connectedness, primarily by renaming the streets, introducing Italian holidays, tearing down monuments that would remind people of the Kingdom of Yugoslavia, introducing bilingual signs, etc. When Italy capitulated in 1943, the Germans took control. ${ }^{46}$

43 Tone Ferenc, "Okupacijski sistemi na Slovenskem 1941-1945", Okupacijski sistemi med drugo svetovno vojno, I: Razkosanje in aneksionizem, ed. Mitja Ferenc, (Ljubljana: Oddelek za zgodovino Filozofske fakultete Univerze v Ljubljani, 2006), 72-76.

44 Ibid., 71.

45 The main resistance movement, originally called the Anti-Imperialist Front, and then renamed to the Liberation Front (OF), was founded on April 27, 1941 in Ljubljana. Soon, the Communist Party of Slovenia, which was an integral part of the Communist Party of Yugoslavia, took on the main role without major problems. The extent of the resistance movement concerned and scared the Italians. They knew that the Partisans had their main bas in Ljubljana. Since the rebellious movement was so strong, all radio receivers were seized in 1942, mainly to prevent people from listening to Radio Kričač. They tried to cut the city from the surrounding area, so they seized all the bicycles and skis, but to no effect. That's when General Robotti decided to surround the city with barbed wire on February 22, 1942. Free movement from and to the city was prohibited and passes were required. When the city was completely surrounded, disarmament of the population took place between February 24 and March 15. Many Slovenians were taken to concentration camps and a campaign of intimidation took place. But despite these measures, the operation of the Liberation Front did not diminish. The Italians responded with another, more fortified zone of barbed wire around the city. 53 bunkers were also built to help eliminate potential resistance. By December 1942, additional 73 bunkers were built in order to scare the population and inflict loses to the Partisans. Together with those in town, there were 206 bunkers all together. The wires affected the entire population of Ljubljana, making everyday life difficult. Repe, $S$ puško in knjigo.

46 On September 10, 1943, immediately after the capitulation of Italy, the Adriatic operational zone was set up. It covered southern Slovenia, the Croatian coast, Istria and Friuli. The six provinces (Ljubljana, Reka, Pula, Trieste, Gorizia and Udine) had their seat in Trieste. For more information see: Tone Ferenc, "Ustanovitev operacijske cone 'Jadransko primorje' in pokrajinske uprave za Ljubljansko pokrajino", Slovenska novejša zgodovina: od programa Zedinjena Slovenija do mednarodnega priznanja Re- 


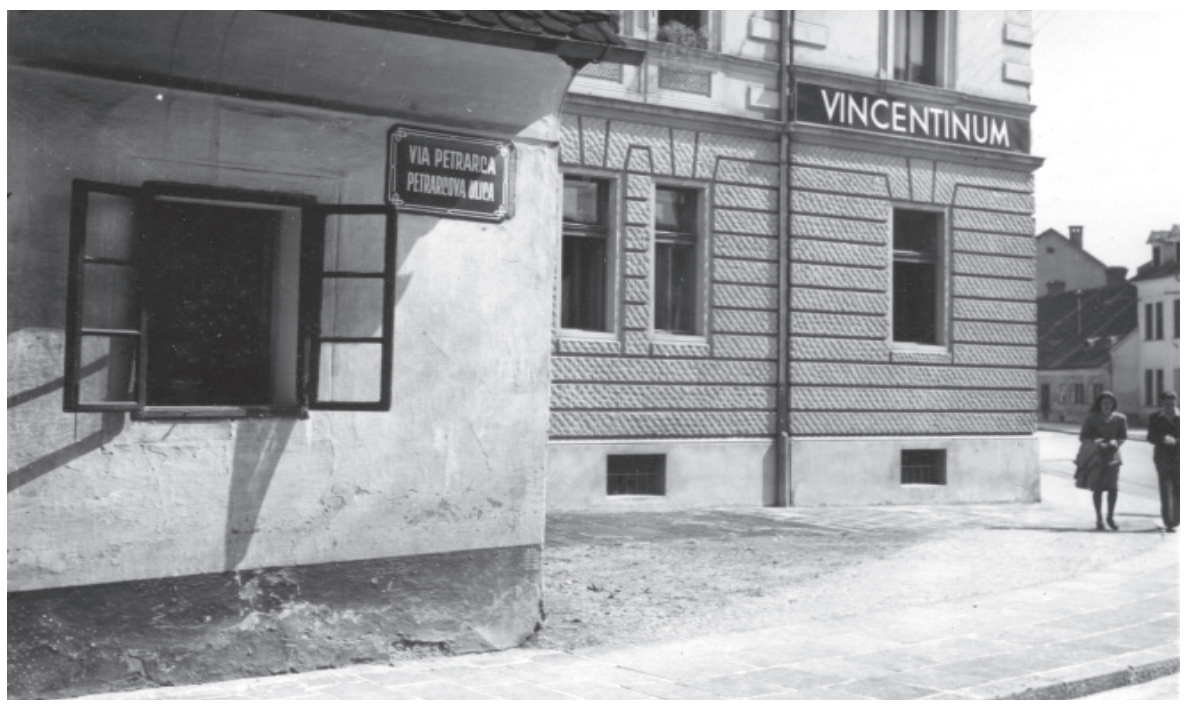

Bilingual street sign in Ljubljana during the Italian occupation. Komenskega Street was renamed Petrarca Street. (Source of photograph: National Museum of Contemporary History)

\subsection{Renaming of Streets}

The Italian occupation authorities made sure that street names in Ljubljana were renamed quickly in order to erase the memory of the affiliation of the city and the people to the Yugoslav state. The Serbian names of the political and cultural life of the Slavic nations were to be predominantly erased. The occupying authorities loathed even the names of Slovenian places, known for the battles of World War I, or the names associated with the oppressive Italian politics in the Primorska region. Some street names in the center of Ljubljana were abolished, so that the streets could be named after people from Italian cultural life. The High Commissioner selected the streets to be renamed, for some of which he chose the names himself. ${ }^{47}$ Other new names were chosen by the Cultural Committee, which, on the basis of the received orders, proposed other new names for the streets. ${ }^{48}$

publike Slovenije: 1848-1992, I-II, ed. dr. Jasna Fischer, (Ljubljana: Mladinska knjiga, 2005), I/691-696.

47 Vlado Valenčič, Zgodovina ljubljanskih uličnih imen, (Ljubljana: Historical Archives: Partizanska knjiga, 1989), 208.

48 ZAL Lj, Reg. I, II A/6 no. 37.290/44, documents no. 30.570/41, 47.090/41 in $58.567 / 43$. 
The Italian occupation authorities were not satisfied simply to rename streets and squares. They also introduced bilingual signs.$^{49}$ Since the costs of replacing all monolingual streets and house signs would be too high, they only put bilingual signs at the beginning of the streets and at intersections, while the house signs remained in Slovene..$^{50}$

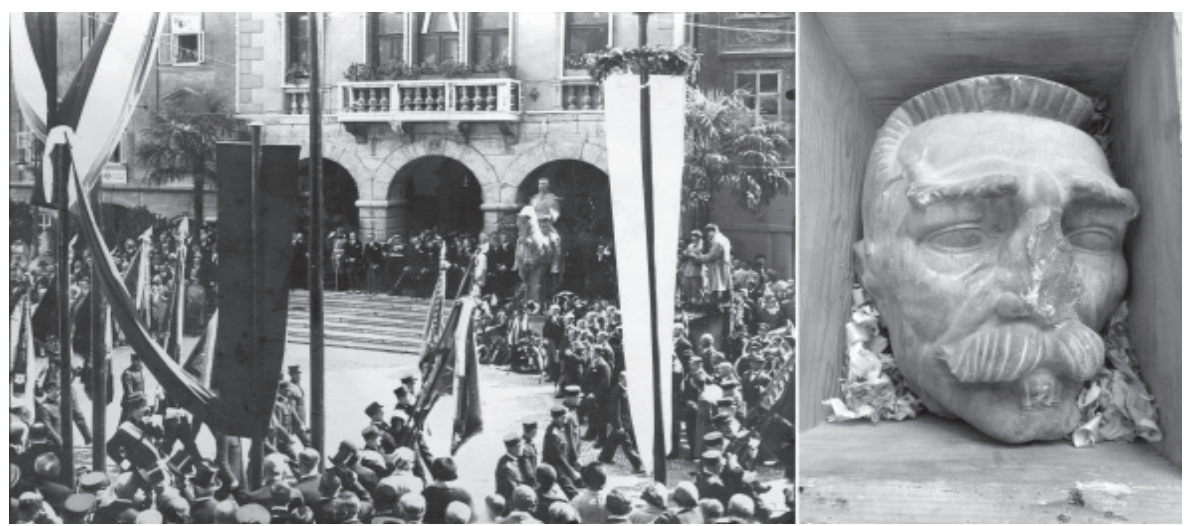

Immediately after the occupation of Ljubljana, the Italians removed the statues of kings Peter I (photo on the left) and Alexander I. They promised to move the statues to the National museum, but they destroyed both instead. On the right side of the photograph, the head of King Peter I, which is currently kept by the National Museum of Contemporary History. (Source of photograph: National Museum of Contemporary History)

\subsection{Removal of Monuments}

The Italians removed monuments that reminded people of the Kingdom of Yugoslavia. The equestrian statue of King Alexander, built in September 1940, lasted only a few months. Together with the statue of King Peter, it was destroyed a few weeks after the occupation started, in the summer of 1941. Alexander's monument was sawed up, while the monument of King Peter was blown up, despite promises by the Italian authorities to take the statues to the museum. ${ }^{51}$ The base of the monument was also destroyed with a concrete crusher, while trucks removed the stones and gravel. The work lasted a few days or nights. The area around Alexander's monument was covered with boards and guarded by the carabinieri. ${ }^{52}$

49 ZAL Lj, Reg. I, II A/6 no. 37.290/44, documents 29.150/41 in 30.401/41.

50 Valenčič, Zgodovina ljubljanskih uličnih imen, 214.

51 Jezernik, Mesto brez spomina, 428.

52 Makso Šnuderl, Dnevnik 1941-1945, I: V okupirani Ljubljani, (Maribor: Obzorja, 1993), 132. 


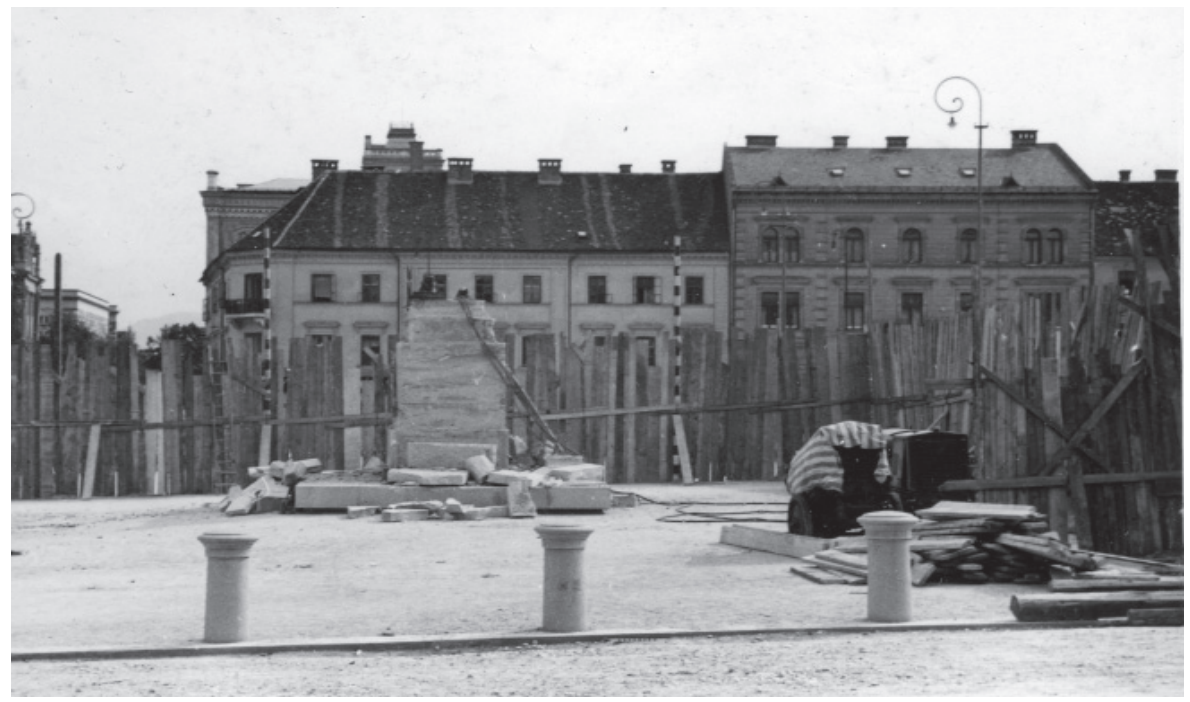

At the end of July 1941, the Italians demolished the monument to King Alexander I Karadjordjević in Ljubljana. The bronze cast of the king was disassembled and most likely remelted. (Source of photograph: National Museum of Contemporary History)

\section{Period of the "Second" Yugoslavia (1945-1991)}

Even in the post-war Yugoslavia, the new power and its new ideology established itself through monuments and denominations. The renamings were largely related to the resistance movement during World War II. The common framework of the Yugoslav state was represented by the National Liberation Struggle (NOB), which was the focal point of the collective memoria of Yugoslavism. The new authorities built monuments primarily to "implement the sociopolitical and moral-ethical obligation of society to the monuments of the National Liberation Struggle and the Socialist Revolution" ${ }^{53}$ and because it wanted to encourage the cultivation of the tradition of the NOB, which should have been one of the foundations of the educational process and socialist consciousness. At the same time, it was supposed to promote class consciousness, as well as the awareness of the need to strengthen the organization of the general popular resistance. The monuments were to guard and revive the achievements and cultural values of the revolution permanently ${ }^{54}$ New authorities meant new names for streets, squares and institutions in Ljubljana.

53 "Spomeniki NOB", Zbor občanov XVI, 13, 1976, 18.

54 Ibid., 18. 
Their role was to replace the names of the occupiers or the old names of the Kingdom of Yugoslavia, thus establishing a new order and a new collective memory of socialist Yugoslavia.

\subsection{Renaming of Streets}

Immediately after the war, the most problematic street and square names were the ones from the time of the Italian occupation. In 1947, some of the streets from that period were changed back to their pre-war names: Marconi Street to Car Dušan Street; Natlačenova Street to Cyril-Methodius Street; Verdi Street to Gajeva Street; Arielle Rea Street to Gosposvetska Street; Puccini Street to Knafljeva Street; Petrarca Street to Komenskega Street; Quagli Street to Kumanovska Street; 800 years of Ljubljana Street to Masarykova Street; etc. ${ }^{55}$ The City People's Committee wanted to preserve the historical tradition of Ljubljana and therefore the continuity of some names, but in practice, it turned out that the establishment of the new order had higher priority. Article 3 of the Decree on the names of settlements and the denomination of streets and houses, adopted in February 1948, stipulated the following: "Settlements must not have names that are not in accordance with today's social and national realities, or which insult the national sense of the Slovenian nation or other Yugoslav nations." ${ }^{56}$ In accordance with Article 9 of said Act, the names of settlements had to be adjusted within one year, but the renamings occurred at a slower pace. The majority of renaming was completed by a government decree in $1955 .{ }^{57}$ The decree's first article lists those amendments that were in accordance with the aforementioned Article 3 of the 1948 Law, and there were 114 such changes. There are two basic types of local names that did not correspond to the spirit of the times: names derived from the Christian tradition, and names that were associated with Germans or Italians or originated from German or Italian speaking areas or were the heritage of feudalism. ${ }^{58}$

Therefore, in Ljubljana, all names with religious connotation disappeared and were replaced by revolutionary names (for example, St.

55 Valenčič, Zgodovina ljubljanskih uličnih imen, 219.

56 Zakon o imenih naselij in označbi trgov, ulic in hiš, Uradni list LRS 10/1948.

57 Decree on the renaming of settlements, supplementing the names of settlements that share a name, and other corrections to the names of the settlements. Official Journal LRS 21/1955.

58 Mimi Urbanc, Matej Gabrovec, "Krajevna imena: poligon za dokazovanje moči in odraz lokalne identitete", Geografski vestnik, 2005, LXXVII, 2, 25-43. 
Rok Street was renamed Dražgoška Street; St. Florian Street was renamed Milan Majcen Street (national hero), Svetokriška Street was renamed Na Žalah, etc. $)^{59}$

After 1952, a number of streets and squares were renamed and named. The urban area was extended by annexing the neighboring settlements and expanding the suburbs. The number of new streets that needed new names increased. It was still believed that the names of streets and squares should be consistent with the new times, that is, they set up collective memoria points.

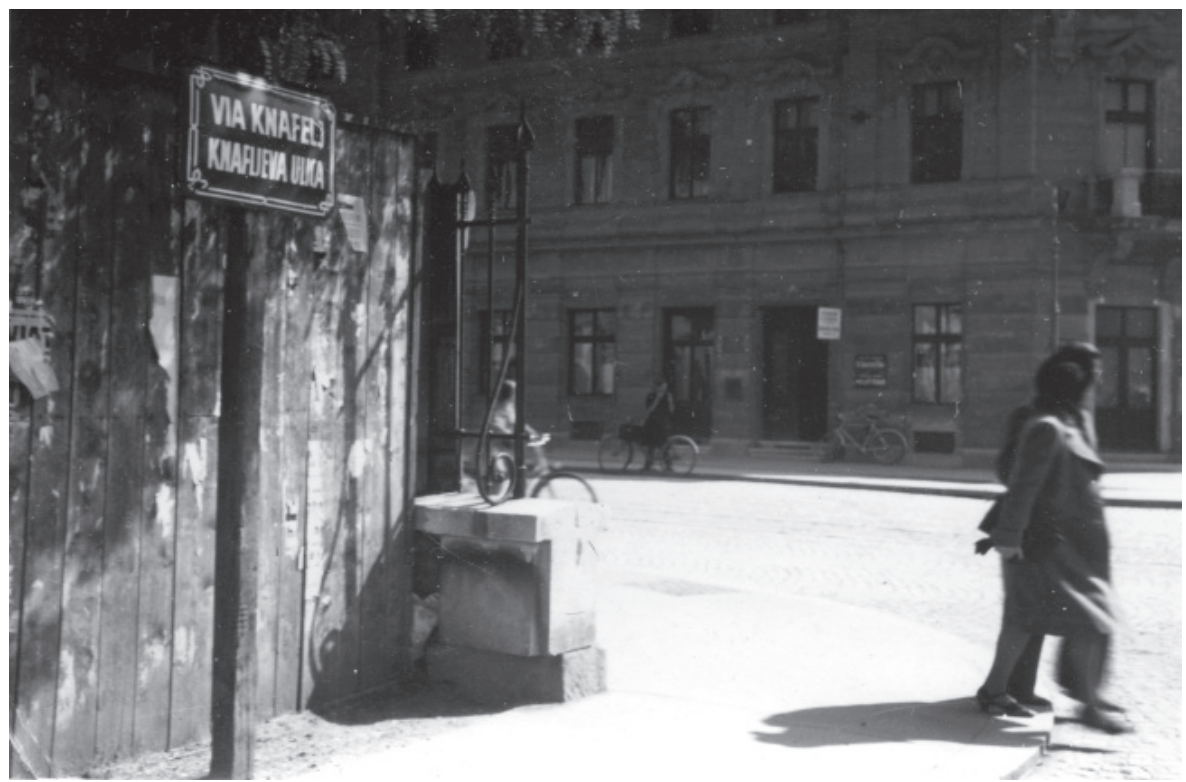

Knafljeva ulica/Knafelj Street (in the photograph it still bears the sign from the time of the Italian occupation) was renamed Tomšičeva ulica/Tomšič Street after the war. (Source of photograph: National Museum of Contemporary History)

\subsection{Renaming of Institutions}

It was not only streets that were subject to renaming, but institutions as well. Immediately after World War II, for instance, the University of Ljubljana lost its German name, assigned by the German occupation authorities. Decades later SFRY collective memoria was consolidated through another renaming of the university: "Policy demands as to what

59 ZAL Lj, MLO, Zapisnik II. seje Mestnega ljudskega odbora glavnega mesta Ljubljana (June 4 1952, 57 sl). 
the University should be and how its professors and students should think, were symbolically indicated during the celebration of its 60th anniversary at the end of 1979, when it was named after recently deceased leading Slovenian communist Edvard Kardelj." ${ }^{60}$

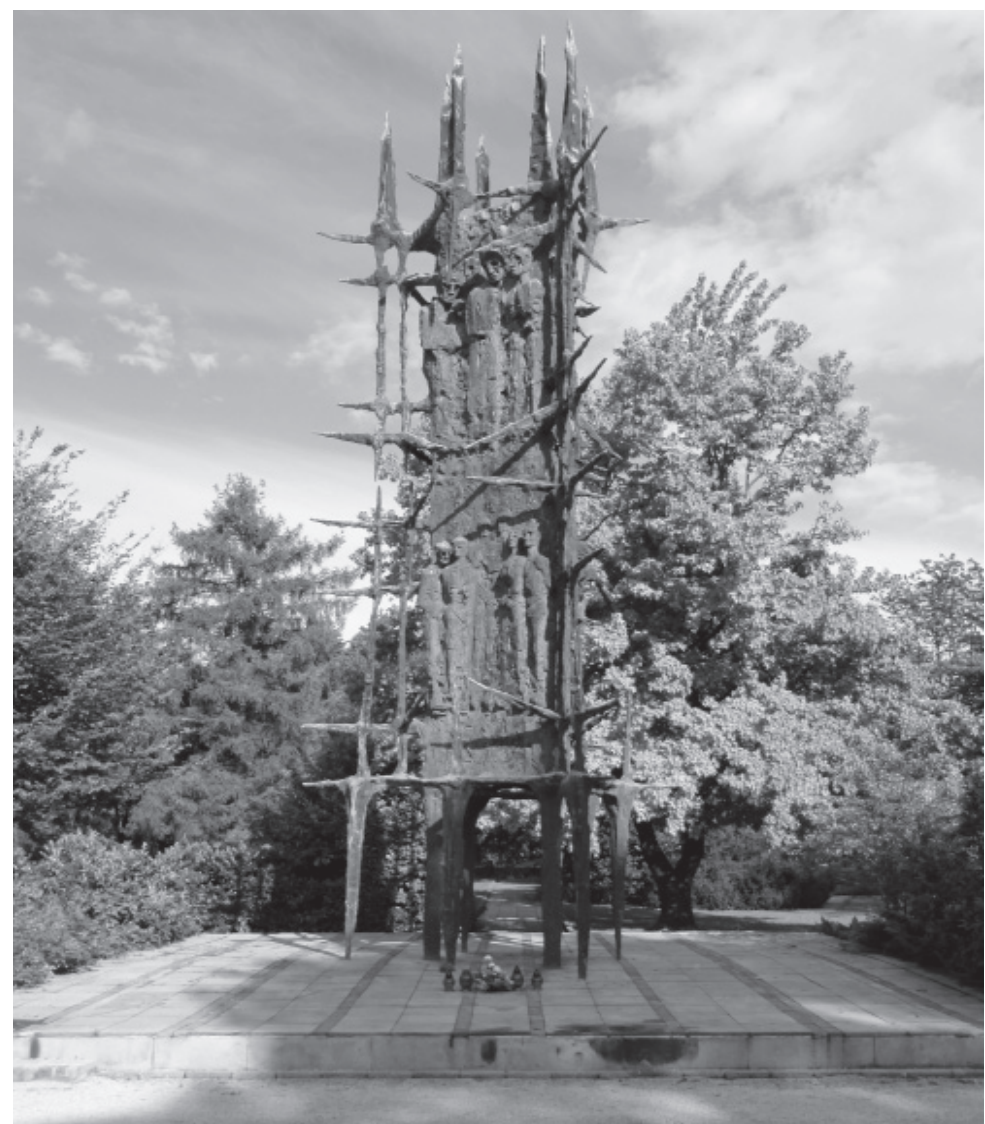

Monuments erected after the year 1945.

(Source of photograph: Veronika Škofljane)

\subsection{Monuments}

Similar to renaming streets and institutions, building monuments also had a political function: "In the newly emerging countries, monuments received a special kind of attention. The radical changes in the political sys-

60 Aleš Gabrič, "Odpuščanje zaradi politično-ideoloških vzrokov", Nova Revija, 2000, XIX, 223/224, 49. 
tem usually led to changes in the symbolic order of the state, which means the removal of the symbols of the old order, and the introduction of those symbols that represent the new ideology and the new political leadership." ${ }^{\prime 1}$ In 1976, similar official resolutions of the authorities on the monuments encountered in the renamings could still be found. One of the basic purposes of the measures regarding the preservation of monuments was for the regulations to "permanently preserve and revive the acquisitions and cultural values of our revolution" and "encourage fostering NOB traditions, which must be one of the cornerstones of our educational process and socialist consciousness." ${ }^{2}$ Even two years later, newspaper titles such as "NOB Monument Protection - A Moral Ethical Obligation of Society" ${ }^{13}$ could be found.

\section{Beginning of "New" Era - Independence of Slovenia (1991-)}

Erasing and denying Yugoslavism was typical for the period after the formal act of declaring Slovenia's independence, but it was already present in the late 1980s, when the processes that led to the dissolution of the SFRY had already begun. When one speaks about the historical context of erasing Yugoslav monuments, one is speaking, in fact, about the period of independence and democratization of Slovenia. Although erasing was the most intense in the early 1990s, it has been present the entire time since the country's declared independence.

At the end of the 1980s, ideas of a multiparty system had engulfed Slovenia. Faced with the economic and political crisis in Yugoslavia, frictions arose and loud demands for a change in the system. Civil society, which then played an important role in the independence of Slovenia, was revived. ${ }^{64}$ In this context, the plebiscite on the independence of Slovenia, which took place on December 23, 1990, was quite important. $88,2 \%$ of Slovenes (with a 93,3\% participation) chose independence and autonomy. The Slovenian story with Yugoslav federalism ended with independence, the adoption of the new Constitution in December 1991, simulta-

61 Božidar Jezernik, "Moč spomina, premoč pozabe: Zgodovina ljubljanskih 'nacionalnih spomenikov'", Zgodovina za vse: vse za zgodovino, 2004, XI, 1, 16.

62 "Spomeniki NOB", Zbor občanov XVI, 13, 1976, 18.

63 Artur Boroje, "Skrb za spomenike NOB - moralno etična obveznost družbe", Dogovori, 1977, V, 13/14.

64 Božo Repe, "Slovenci in Jugoslavija po drugi svetovni vojni", Zgodovina v šoli, 1995, IV, 1,28 . 
neous international recognition, and admission to the United Nations in May 1992. ${ }^{65}$ A new chapter in Slovene history had begun.

The Slovenian post-independence political elite started reforming the collective memory after the independence. This was most obvious during the Demos administration, which was characterized by a reluctant attitude to everything related to the previous regime. The said government emphasized its inclination for a general removal of socialist symbols in its program. ${ }^{6}{ }^{6}$

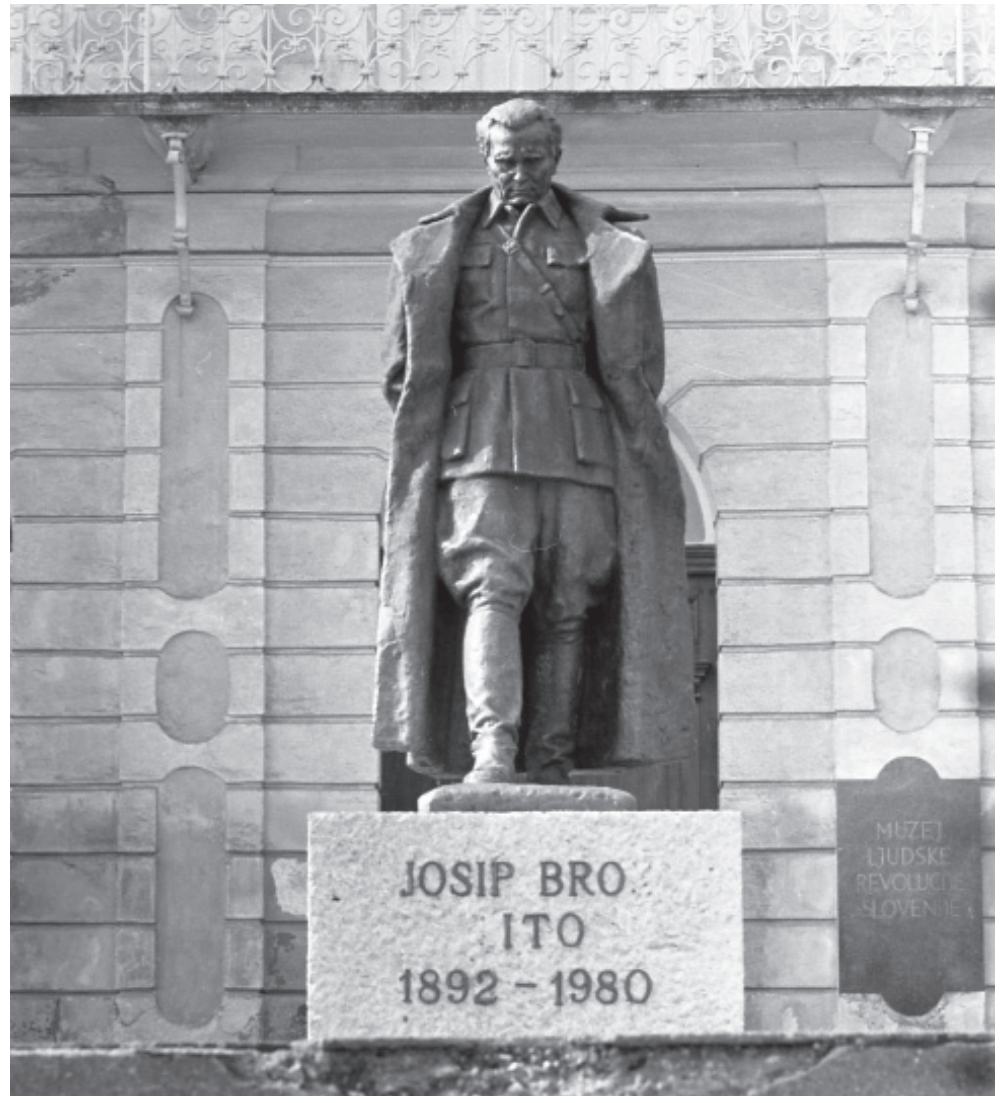

In Slovenia, monuments to Tito were often targets of vandalism in the early nineties. A bronze cast of Tito, which had once stood in front of the National Museum of Contemporary History, was also removed. (Source of photograph: National Museum of Contemporary History)

65 Ibid., 29.

66 Barbara Šterbenc Svetina, "Pot spominov in tovarištva med osamosvajanjem Slovenije”, Glasnik Slovenskega etnološkega društva, 2002, XLII, 1-2, 41. 


\subsection{Renaming of Streets}

Renaming and abolishing streets and squares was the most intense in the year of independence. In 1991, there were 26 renamings of streets with a Yugoslav connotation in Ljubljana alone ${ }^{67}$ After a six-year silence, a new renaming action was launched in 1997, albeit considerably on a smaller scale, as it included only five streets. ${ }^{68} \mathrm{New}$ renamings followed in 1998, when six streets were renamed..$^{69}$ The year 2000 brought only one change, ${ }^{70}$ as did the year $2010 .{ }^{71}$

\subsubsection{The Tito Road Controversy}

The controversy surrounding Tito Road started in 2009, when the Ljubljana City Council adopted a decree renaming a part of Štajerska Road - from the square at the Plečnikove Žale cemetery and the newly planned northern artery to Tomačevo Circle - to Tito Road. The decision provoked a strong public reaction and a number of public debates were held on the suitability of such a name. ${ }^{72}$ In 2011, the Constitutional Court considered the arguments of all parties and in the process of assessing the constitutionality and legality decided to abolish ${ }^{73}$ the article of The Ordinance on Determining and Changing the Names and Course of the Roads and Streets on the Territory of Ljubljana Municipality, thus denying the possibility of a street being named after Tito.

67 "Odlok", Uradni list, št. 78, 5. 10. 2011, 10079, date of access November 2015, http:// www.uradni-list.si/1/objava.jsp?urlurid=20113301 in "Odlok o določitvi, spremembi in ukinitvi imen oziroma potekov cest, ulic, poti in trgov na območju mesta Ljubljane", Uradni list, št. 21, 31. 10.1991, 789, date of access November 2015, https://www.uradni-list.si/1/content?id=60959. „Odlok o določitvi...”, Uradni list, št. 20, 841-842.

68 „Odlok o določitvi, spremembi in ukinitvi imen oziroma potekov cest, ulic, poti in trgov na območju mesta Ljubljane", Uradni list, št. 22, 18. 4. 1997, 1804, date of access November 2015, http://www.uradni-list.si/1/objava.jsp?urlurid=19971291.

69 „Odlok o določitvi, spremembi in ukinitvi imen oziroma potekov cest, ulic, poti in trgov na območju Mestne občine Ljubljana“, Uradni list, št. 18, 6. 3.1998, 1184, date of access November 2015, http://www.uradni-list.si/1/objava.jsp?urlurid=1998752.

70 „Odlok o določitvi in spremembi imen ulic na območju Mestne občine Ljubljana“, Uradni list, št. 31, 7. 4. 2000, 3808, date of access November 2015, http://www.uradni-list.si/1/objava.jsp?urlurid=20001461.

71 „Odlok o določitvi imen ulic, potekov in sprememb potekov ulic na območju Mestne občine Ljubljana“, Uradni list, št. 60, 23. 7. 2010, 9089, date of access November 2015, http://www.uradni-list.si/1/objava.jsp?urlurid=20103319.

72 Matjaž Albreht, „Sodišče odločilo, da poimenovanje Titove ceste ni ustavno“, Delo, October 4, 2011, date of access November 2015, http://www.delo.si/novice/slovenija/ sodisce-odlocilo-da-poimenovanje-titove-ceste-ni-ustavno.html.

73 Ibid. 


\subsection{Removal and Installation of Monuments}

Although many monuments and memorials associated with Yugoslavia can still be found today in the Ljubljana area, ${ }^{74}$ many such commemorations have been removed in the period after 1991 . The real controversy was triggered by the removal of the seven flag masts that stood along the Trail of Remembrance and Comradeship since $1984 .^{75}$ Ljubljana Municipal Minister Janez Lesar ordered the masts to be cut down on April 22, 1991, just prior to the traditional march along the barbed wire of occupied Ljubljana. The masts have never been reinstalled and it is unknown what has happened to them. The monument of Ljubljana in Battle was also removed from the courtyard of the Exhibition and Convention Center, while a monument to the Partisan Courier was removed from the Pohorje Battalion Street. ${ }^{76}$

\subsubsection{Statues of Josip Broz Tito}

Under most fierce attacks were the statues of Josip Broz Tito. Numerous busts that depicted him were transferred from public institutions and companies to museums during that time. The white marble statue of Tito was removed from the lobby of the Slovenian National Assembly ${ }^{77}$ as early as 1990 and moved to the City Museum of Ljubljana. ${ }^{78}$ The bronze cast of Tito, which stood in front of the Museum of Modern History was moved to a storage vault "for renovation" and from there to an unknown location. ${ }^{79}$ The advocates of such actions emphasized that the removal of these two monuments did not necessarily mean their destruction but

74 It is impossible to list all the still existing monuments set up in the previous social-political system and are associated with Yugoslavism, but some of them can be mentioned: Monument of the Revolution (Republic Square), Monument of the Illegal (near Štefanova Street), Monument of the Liberation Front Foundation (27 April Road in front of the Vidmar Villa), Monument to the Fallen Soldiers in the National Liberation Front (Šentvid, Lower Šiška, and Trnovo), the Kardelj Monument (Republic Square), etc.

75 The Trail of Remembrance and Comradeship, also known as the Trail Along the Wire, is a $32,5 \mathrm{~km}$ long route around Ljubljana. It runs along the barbed wire route, which surrounded the city under the Italian occupation during World War II (between February 23, 1942 and May 26, 1945).

76 Sara Arko, "Kje so spomeniki?: usode ljubljanskih spomenikov iz časa Titove Jugoslavije", (Term paper, Filozofska fakulteta, Univerza v Ljubljani, 2006), 5-9.

77 Former Assembly of the Socialist Republic of Slovenia.

78 Jezernik, "Moč spomina, premoč pozabe", 16.

79 Špelca Čopič in drugi, Outdoor sculpture in Ljubljana, (Ljubljana: Državna založba Slovenije, 1991), 26 in 15-1. 
merely "their removal from public spaces" and their placement to "where history is stored - the museum". 80

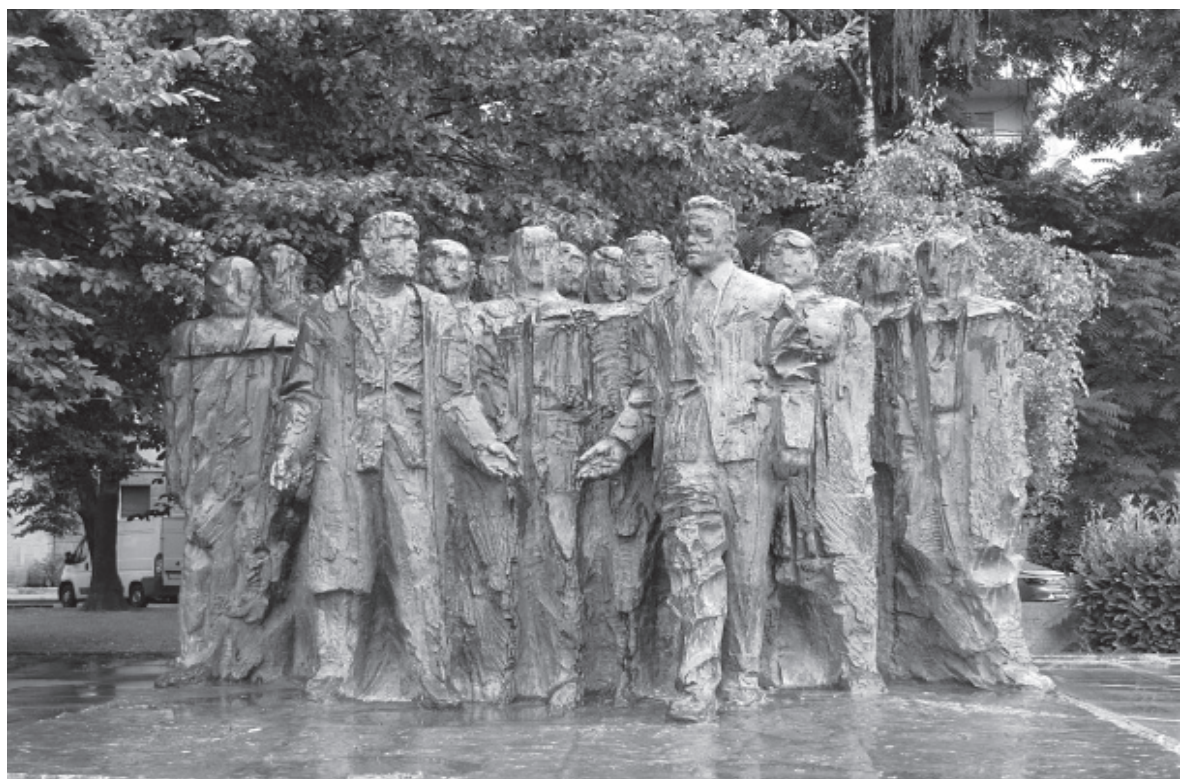

Two monuments to Edvard Kardelj and Boris Kidrič in Ljubljana still stand today, despite several campaigns to have them removed. (Source of photograph: Veronika Škofljanec)

While addressing the statues of Josip Broz Tito, we can lastly note that the sculptures of other communist officials were also removed from public institutions, for instance the bust of Edvard Kardelj that used be located on the building of the municipal office of Vič-Rudnik and was removed just before Slovenia declared independence. ${ }^{81}$

In 1995, the Ljubljana City Council initiated a campaign to remove "monuments to the workers' movement, the NOB, and the socialist construction," ${ }^{\prime 2}$ and also to remove the Boris Kidrič monument from Prešern Road, as well as the monument to Edvard Kardelj from Republic Square. The proposal to remove those monuments triggered a very intense debate. The central Slovene daily newspaper Delo even introduced a special section for readers' letters called "Monuments Yes, Monuments No" ${ }^{83} \mathrm{Nu}-$

80 Dimitrij Kovačič, "Del zgodovine sta Kardelj in Kidrič in ne njuna spomenika", Slovenec $86,30$.

81 Miha Štamcar, "Nova imena starih napak”, Mladina, 25. 7. 1990, 31.

82 Jezernik, "Moč spomina, premoč pozabe", 16.

83 Janez Stibrič, “Zbiranje podpisov proti rušenju spomenikov”, Delo 134/1996, 16. 
merous readers agreed with the proposal, stating that "even the former Soviet Union had removed the communist-era statues of Stalin and similar executioners."

But on the other hand, "such vandalism" has been ardently opposed by many, especially former partisans, who strongly protested against the destruction of monuments dedicated to their military leaders. ${ }^{84}$

Their opponents also suggested taking down the statue of Boris Kidrič and building a monument to the unknown hero instead, and replacing the statue of Edvard Kardelj with a monument honoring independent Slovenia. ${ }^{85}$ Despite the efforts of the opponents, the monuments were not removed and are still standing in their place.

\section{Renaming of Elementary Schools}

Elementary schools are basic educational institutions in all modern societies, so their name usually implies a reigning ideology or fundamental values advocated by a particular socio-political system. Thus, in the previous political era, elementary schools usually bore names of national heroes. In the post-independence period, mass renamings occurred, ${ }^{86}$ although some names from the SFRY era were preserved. ${ }^{87}$ Often the opposition came from the school councils. ${ }^{88}$

84 Jezernik, "Moč spomina, premoč pozabe", 16.

85 Nevenka Žolnir, "Kidričše kar vznemirja nekatere mestne svetnike”, Delo, 17. 7. 1997, 4.

86 For example, Zvonko Runko Elementary School was renamed to Lower Šiška Elementary School ("Sklep o soglasju k preimenovanju osnovnih šol”, Official Gazette, no. 10, 28. 2. 1992, 635, date of access 28. 3. 2018, https://www.uradni-list.si/glasilo-uradni-list-rs/vsebina/62367) and Franc Leskošek Luka Elementary School in Ljubljana was renamed Bičevje Elementary School ("Sklep o soglasju k preimenovanju osnovne šole Franc Leskošek Luka”, Official Gazette, no. 28, 6.12.1991, 1202, date of access 28. 3. 2018, https://www.uradni-list.si/glasilo-uradni-list-rs/vsebina/1991-01-1197/ sklep-o-soglasju-k-preimenovanju-osnovne-sole-franc-leskosek-luka).

87 Eight more schools are named after national heroes of the National Liberation Front as of today. These are the following: Danila Kumar Elementary School, Majda Vrhovnik Elementary School, Vida Pregarc Elementary School, Oskar Kovačič Elementary School, National Hero Maks Pečar Elementary School, Dr. Vito Kraigher Elementary School, Milan Šuštaršič Elementary School, and Franc Rozman Stane Elementary School.

88 Dejan Vodovnik, „Sveti desetih osnovnih šol proti spremembam imen“, Delo, 20. 5. 1997, 4; Dejan Vodovnik, „Samo dve šoli se bosta imenovali drugače“, Delo, 13. 6. 1997, 5 . 


\section{Sources and Literature}

\section{Unpublished Sources}

- $\quad$ Historical Archives Ljubljana: Cod. III/77 (1919), fol. 128 sl. 5; Reg. I fasc 1615; fol. 275; Reg. I fasc 2047, fol. 126 in 805 sl.; Reg. I, II A/6 št. 37.290/44, spisa št. 30.570/41, 47.090/41 ter 58.567/43; MLO, Zapisnik II. seje Mestnega ljudskega odbora glavnega mesta Ljubljana (4. junij 1952, str. 57 sl).

\section{Literature}

- $\quad$ Arko, Sara. "Kje so spomeniki?: usode ljubljanskih spomenikov iz časa Titove Jugoslavije”. Term paper, Filozofska fakulteta, Univerza v Ljubljani, 2006.

- Boroje, Artur. "Skrb za spomenike NOB - moralno etična obveznost družbe”. Dogovori. Ljubljana, 1977, V, 13/14.

- $\quad$ Čopič, Špelca in drugi. Outdoor sculpture in Ljubljana. Ljubljana: Državna založba Slovenije, 1991.

- Čopič, Špelca. Javni spomeniki v slovenskem kiparstvu prve polovice 20. stoletja. Ljubljana: Moderna galerija, 2000.

- Čubrilo, Jasmina. "Dva spomenika Sretena Stojanovića: Kontinuiteta V diskontinuiteti". Acta historiae artis Slovenica, 2013, XVIII, 2, 73.

- Ferenc, Tone. "Ustanovitev operacijske cone 'Jadransko primorje' in pokrajinske uprave za Ljubljansko pokrajino". Slovenska novejša zgodovina: od programa Zedinjena Slovenija do mednarodnega priznanja Republike Slovenije: 1848-1992, I-II, ur. dr. Jasna Fischer. Ljubljana: Mladinska knjiga, 2005, I/691-696.

- $\quad$ Ferenc, Tone. “Okupacijski sistemi na Slovenskem 1941-1945”. Okupacijski sistemi med drugo svetovno vojno, I: Razkosanje in aneksionizem, ed. Mitja Ferenc. Ljubljana: Oddelek za zgodovino Filozofske fakultete Univerze v Ljubljani, 2006, 71-78.

- Gabrič, Aleš. "Odpuščanje zaradi politično-ideoloških vzrokov". Nova Revija, 2000, XIX, 223/224, 17-49.

- Gangl, Engelbert. Kažipot Ljubljana, Gorenjsko, Notranjsko s Postojno, Dolenjsko, Trst. Ljubljana: Slovenska Sokolska Zveza, 1914.

- Jezernik, Božidar. "Moč spomina, premoč pozabe: Zgodovina ljubljanskih 'nacionalnih spomenikov'". Zgodovina za vse: vse za zgodovino, 2004, XI, 1, 5-18.

- Jezernik, Božidar. Nacionalizacija preteklosti. Ljubljana: Znanstvena založba Filozofske fakultete Univerze v Ljubljani, 2013.

- Jezernik, Božidar. Mesto brez spomina: Javni spomeniki v Ljubljani. Ljubljana: Modrijan, 2014.

- Jurić Pahor, Marija. "Memorija in/ali spomin? Raziskovalni trendi in pojmovne zagate". Razprave in gradivo, 2007, 53-54, 204-228.

- Komić Marn, Renata. "Možje na konjih: Vloga in recepcija konjeniškega spomenika na Slovenskem". Acta historiae artis Slovenica, 2013, XVIII, 2, 97. 
- $\quad$ Kramberger, Taja. Historiografska divergenca: razsvetljenska in historična paradigma: o odprti in zaprti epistemični strukturi in njunih elaboracijah. Koper: Založba Annales, 2007.

- Kramberger, Taja. "Zapletena razmerja: Spomin, memorija, pozaba, zgodovina". Emzin, 2009, XIX, 3-4, 55-57.

- Makuljević, Nenad in Barbara Murovec. "Uredniška beseda”. Acta historiae artis Slovenica, 2013, XVIII, 2, 3.

- Mikša, Peter. "'Da je Triglav ostal v slovenskih rokah, je največ moja zasluga.' Jakob Aljaž in njegovo planinsko delovanje v Triglavskem pogorju". Zgodovinski časopis, 2015, LXIX, 1/2, 112-123.

- Misztal A., Barbara. Theories of Social Remembering. Maidenhead. Philadelphia: Open University Press, 2003.

- Perovšek, Jurij. “Jugoslovanska združitev”. Slovenska novejša zgodovina: od programa Zedinjena Slovenija do mednarodnega priznanja Republike Slovenije: 1848-1992, I-II, ed. dr. Jasna Fischer. Ljubljana: Mladinska knjiga, 2005, I/200-203.

- $\quad$ Repe, Božo. "Slovenci in Jugoslavija po drugi svetovni vojni”. Zgodovina v šoli, 1995, IV, 1, 20-30.

- $\quad$ Repe, Božo. S puško in knjigo: narodnoosvobodilni boj slovenskega naroda 1941-1945. Ljubljana: Cankarjeva založba, 2015.

- $\quad$ Rozman, Ksenija. “Ljubljanski javni spomeniki”. Kronika, 1965, XIII, 2, 196203.

- Svetina Šterbenc, Barbara. "Pot spominov in tovarištva med osamosvajanjem Slovenije”. Glasnik Slovenskega etnološkega društva, 2002, XLII, 1-2, 40-42, 107.

- Šnuderl, Makso. Dnevnik 1941-1945, I: V okupirani Ljubljani. Maribor: Obzorja, 1993.

- Urbanc, Mimi, Matej Gabrovec. "Krajevna imena: poligon za dokazovanje moči in odraz lokalne identitete". Geografski vestnik, 2005, LXXVII, 2, 25-43.

- Valenčič, Vlado. Zgodovina ljubljanskih uličnih imen. Ljubljana: Historical Archive: Partizanska knjiga, 1989.

- Zupan, Gojko. "Razvoj spomenikov NOB v Ljubljani”. Sinteza: revija za likovno kulturo, 1985, 69-72, 145, 146.

- “Kronika Ljubljane 1945-1965”. Kronika: časopis za slovensko krajevno zgodovino. Ljubljana: Zveza zgodovinskih društev Slovenije, 1965, XIII, 1, 3-31.

- "Spomeniki NOB”. Zbor občanovXVI, 13, 1976, 18.

- Kovačič, Dimitrij. "Del zgodovine sta Kardelj in Kidrič in ne njuna spomenika”. Slovenec 86, 30-31.

- $\quad$ Štamcar, Miha. “Nova imena starih napak”. Mladina, 25. 7. 1990, 31.

- Vodovnik, Dejan. "Sveti desetih osnovnih šol proti spremembam imen". Delo, 20. 5. 1997, 4 . 
- $\quad$ Vodovnik, Dejan. "Samo dve šoli se bosta imenovali drugače”, Delo, 13. 6. 1997, 5.

Žolnir, Nevenka. "Kidrič še kar vznemirja nekatere mestne svetnike”. Delo, 17. 7.1997, 4 .

\section{Internet sources}

Albreht, Matjaž. "Sodišče odločilo, da poimenovanje Titove ceste ni ustavno". Delo, 4. oktober 2011. Date of access November 2015. http://www.delo.si/ novice/slovenija/sodisce-odlocilo-da-poimenovanje-titove-ceste-ni-ustavno.html

- Inštitut za slovenski jezik Frana Ramovša ZRC SAZU. Iskanje po Slovarju slovenskega knjižnega jezika (1970-1991): spomenik (174). Date of access 30. 1. 2018. http://bos.zrc-sazu.si/cgi/a03.exe?name=sskj_testa\&expression=spomenik\&hs=1.

- $\quad$ M. K. "Ob Njegoševi ulici zdaj tudi kip vladarju, ki je razumel lepoto jezika". MMC RTV SLO, 29. 3. 2018, Ljubljana. Date of access March 2018. https:// www.rtvslo.si/kultura/drugo/ob-njegosevi-ulici-zdaj-tudi-kip-vladarju-ki-je-razumel-lepoto-jezika/337273

- $\quad$ Mrak, Andrej. “Kako so Ljubljančani 'pospravili' za Habsburžani in se prikupili novim oblastnikom. Zamenjava imen ljubljanskih ulic po prvi svetovni vojni". MMC RTV SLO, 10. marec 2012, Ljubljana. Date of access: 25. 2. 2018. http://www.rtvslo.si/kultura/drugo/kako-so-ljubljancani-pospravili-za-habsburzani-in-se-prikupili-novim-oblastnikom/278607

- "Kiparstvo med socialističnim realizmom in konceptualizmom". Pojmovnik slovenske umetnosti 1945-2005. Date of access 28. 3. 2018. http://www.pojmovnik.si/koncept/kiparstvo_med_socialisticnim/

- "Odlok o določitvi, spremembi in ukinitvi imen oziroma potekov cest, ulic, poti in trgov na območju mesta Ljubljane". Uradni list, št. 20,17. 5. 1991, 841. Date of access November 2015. http://www.ljubljana.si/Static/upload/ file/Ulice\%20-\%204_4_1991\%20Uradni\%20list\%20SRS.pdf

"Odlok o določitvi, spremembi in ukinitvi imen oziroma potekov cest, ulic, poti in trgov na območju mesta Ljubljane". Uradni list, št. 21, 31. 10. 1991, 789. Date of access November 2015. https://www.uradni-list.si/1/content?id=60959

"Odlok o določitvi, spremembi in ukinitvi imen oziroma potekov cest, ulic, poti in trgov na območju mesta Ljubljane”. Uradni list, št. 22, 18. 4. 1997, 1804. Date of access November 2015. http://www.uradni-list.si/1/objava. jsp?urlurid=19971291

"Odlok o določitvi, spremembi in ukinitvi imen oziroma potekov cest, ulic, poti in trgov na območju Mestne občine Ljubljana”. Uradni list, št. 18, 6. 3. 1998, 1184. Date of access November 2015. http://www.uradni-list.si/1/ objava.jsp?urlurid=1998752 
- $\quad$ "Odlok o določitvi in spremembi imen ulic na območju Mestne občine Ljubljana”. Uradni list, št. 31, 7. 4. 2000, 3808. Date of access November 2015. http://www.uradni-list.si/1/objava.jsp?urlurid=20001461

- "Odlok o določitvi imen ulic, potekov in sprememb potekov ulic na območju Mestne občine Ljubljana." Uradni list, št. 60, 23. 7. 2010, 9089. Date of access November 2015. http://www.uradni-list.si/1/objava.jsp?urlurid=20103319

- "Odlok". Uradni list, št. 78, 5. 10. 2011, 10079. Date of access November 2015. http://www.uradni-list.si/1/objava.jsp?urlurid=20113301

- $\quad$ "Sklep o soglasju k preimenovanju osnovne šole Franc Leskošek Luka”. Uradni list, št. 28, 6.12.1991,1202. Date of access 28.3.2018. https://www.uradni-list.si/glasilo-uradni-list-rs/vsebina/1991-01-1197/sklep-o-soglasju-k-preimenovanju-osnovne-sole-franc-leskosek-luka

- $\quad$ "Sklep o soglasju k preimenovanju osnovnih šol”. Uradni list, št. 10, 28. 2. 1992, 635. Date of access 28. 3. 2018. https://www.uradni-list.si/glasilouradni-list-rs/vsebina/62367

- "Spomeniki polpretekle zgodovine". Date of access 28. 3. 2018. http:// spomeniki.blogspot.si/

- SSKJ, „Spomenik“, datum pristupa 30. 1. 2018, http://bos.zrc-sazu.si/cgi/ a03.exe?name=sskj_testa\&expression=spomenik\&hs=1.

- "Uredba o preimenovanju naselij, o dopolnitvi imena takih naselij, ki imajo enako se glaseča imena in o drugih popravkih imena naselij". Uradni list LRS $21 / 1955$.

- "Zakon o imenih naselij in označbi trgov, ulic in hiš”. Uradni list LRS 10/1948.

\author{
Newspapers \\ - Jugoslavija \\ - Jugoslovan \\ - Jutro: Monday Issue \\ - Jutro \\ - $\quad$ Kronika slovenskih mest \\ - Slovenec \\ - Slovenski narod \\ - Tedenske slike: supplement to Domovina \\ - Učiteljski tovariš
}




\section{Summary}

The idea of uniting the Yugoslav peoples in the commons state is one of the most important perspectives of the 20th century Slovenian history. The elements of Yugoslavism are still present in the Slovene collective memory, which is most evident in numerous memorials and denominations related to Yugoslavism, found in the Slovene public space. They can be traced from the 1920s onwards, while the majority is recorded around the middle of the century. The establishing of the collective awareness in Ljubljana is mostly visible in the political fractures - such as the break with the Austro-Hungarian Monarchy, and the entry into the State of Slovenes, Croats and Serbs and Kingdom of Serbs, Croats and Slovenes, when it was necessary to redefine the collective memoria, and remove the old one. That is very noticeable in the changing of the names of streets and institutions, and in demolishing and erecting new monuments, and the even more obvious marking of space - the post-war order. The process was also distinct during the occupation of Slovenia, when the Italians invaded Ljubljana and the city went through alterations of its characteristics and image, as the occupier wanted to erase the historical memory of the common state with the southern nations. Other examples of this process are the post-war Yugoslavia and post-independence Slovenia. When comparing the processes happening during and after the years 1918, 1941, 1945, and 1991, we conjectured that the process of "marking" the space, both in setting up and tearing down the previous socio-political system was the most intensive in post-war Yugoslavia. We also assumed the process was less intense in the post-independence period than in the period after World War II, but individual cases tended to raise much more controversy both among the experts and the public. The debate on renaming streets and setting up or removing monuments is (was) in many cases a tool of political infighting and a means of polarizing the Slovenian public. 


\title{
Резиме
}

Петер Микша

\section{Југословенство записано у споменицима и деноминацијама у Љубљани}

\begin{abstract}
Апстракт: Циљ овог текста је да прикаже (хронолошки) преглед деноминације, преименовања или укидања улица и тргова, постављања и рушења споменика, именовања и преименовања основних школа и др., са југословенским контекстом, у Љубљани од 1918. године па надаље. Овакво успостављање колективног памћења у Словенији најочигледније је у политички преломним ситуацијама као што су: распад Аустроугарске монархије и улазак у Државу Словенаца, Хрвата и Срба и у Краљевину Срба, Хрвата и Словенаца, када је било потребно редефинисати колективно памћење и избрисати старо. То је најприметније у преименовању улица и институција или рушењу и постављању нових споменика, а још је израженије означавање простора у послератном режиму за време „друге“ Југославије. Процес је био присутан током окупације Словеније између 1941. и 1945. и у периоду постнезависне Словеније након 1991. године.
\end{abstract}

Кључне речи: југословенство, Југославија, споменици, Словенија, Љубљана

Идеја о уједињавању југословенских народа у заједничку државу једна је од најважнијих перспектива словеначке историје 20. века. Елементи југословенства још увек су присутни у словеначком колективном памћењу, што је најочигледније у бројним споменицима и деноминацијама везаним за југословенство који се налазе у словеначком јавном простору. Њихови се трагови могу пратити од 20-их година па надаље, док се у највећој мери бележе око средине 20. века. Успостављање колективне свести у Љубљани највидљивије је у политички преломним ситуацијама, као што је био раскид са Аустроугарском монархијом и улазак у Државу Словенаца, Хрвата и Срба и Краљевину Срба, Хрвата и Словенаца, када је било неопходно редефинисати колективно памћење и уклонити старо. То се по- 
себно види у промени назива улица и институција, као и у рушењу и постављању нових споменика, а било је још очигледније у обележавању простора послератног поретка. Процес је био нарочито упадљив током окупације Словеније, када су Италијани ушли у љубљану и када је град пролазио кроз промене својих основних карактеристика и изгледа, јер је окупатор желео да избрише историјско сећање на заједничку државу са јужним народима. Даљи примери овог процеса су послератна Југославија, а затим и Словенија након стицања независности. Упоређивањем процеса који су се одвијали током и после $1918,1941,1945$. и 1991. закључили смо да је процес „обележавања“ простора, како у успостављању новог тако и у рушењу претходног друштвено-политичког система, био најинтензивнији у послератној Југославији. Такође смо закључили да је процес био мање интензиван у периоду након независности него у периоду након Другог светског рата, али су поједини случајеви тежили да изазову много више контроверзи и међу стручњацима и у јавности. Расправа о преименовању улица и постављању или уклањању споменика у многим случајевима представља оруђе политичке борбе и средство поларизације словеначке јавности. 